ISSN: 2224-0616

Int. J. Agril. Res. Innov. Tech. 10(1): 40-55, June 2020

DOI: https://doi.org/10.3329/ijarit.v10i1.48093

\section{OPEN ACCESS}

Available online at https://ijarit.webs.com https://www.banglajol.info/index.php/IJARIT

\title{
Impacts of cyclone and flood on crop and fish production in disaster prone coastal Bhola district of Bangladesh
}

\author{
M.S. Islam*, M.R. Jamil, M.N. Chowdhury, M.H. Kabir and R.H. Rimi \\ Received 10 April 2020, Revised 24 April 2020, Accepted 20 June 2020, Published online 30 June 2020
}

\begin{abstract}
A B S T R A C T
This study assessed the impact of climate change induced disaster on crops and fisheries production at Bhola Sadar and Monpura upazila of Bhola district, Bangladesh during January to June 2018. The study was gathered primary data from primary observation (PO), questionnaire survey (QS), focus group discussion (FGD), and key informant interview (KII). Secondary data were collected from Upazila Agricultural Office and Upazila Fisheries Office of Bhola Sadar and Manpura upazila and moreover, climatic data were collected from Bangladesh Meteorological Department. Results of the study found that trend analysis indicates overall annual maximum temperature increased for Kharif-I, Kharif-II and Rabi season. Average annual minimum temperature also increased for Kharif-I season but decreased for Kharif-II and Rabi season. Study also found that for all cropping season average relative humidity was increased. Annual average rainfall exhibited decreasing trend for Kharif-I and Rabi season but increased for Kharif-II season in (1990-2019) time period. The Aus, T. Aman, Boro and Mung bean was dominant cropping pattern in Kharif-I, KharifII and Rabi season in Bhola district. Overall, Aus rice production in Kharif-I season increased but in 2009, 2013 production was decreased because of cyclone Aila (2009) and Cyclone Mahasen (2013). T. Aman production hampered due to Cyclone Sidr (2007) and flood (2014) in Kharif-II season. In Rabi season Boro rice production lessen because of low rainfall and salinity intrusion. Overall, Mung bean production increase but in 2008 and 2009 production become hampered due to late cultivation because of Cyclone Sidr (2007). Fish production rate increase in Bhola specially Hilsha fish because of non-climatic factor like raid in non-fishing time, banned current net but fish production in pond become diminished due to infrequent natural disaster. Practicing of salt and flood tolerant varieties, floating bed vegetable cultivation, and mixed cropping system (mainly for Rabi season), enhanced expedition activities against catching mother Ilish in prohibition period, dredging in the heart of the river which can eventually reduce vulnerabilities and increase crop and fish production in the Bhola region.
\end{abstract}

Keywords: Climate change, Cyclone, Flood, Crops, Fish production, Coastal district.

Department of Environmental Science and Resource Management, Mawlana Bhashani Science and Technology University, Tangail-1902, Bangladesh.

*Corresponding author’s email: islammstazu@yahoo.com (M.S. Islam)

Cite this article as: Islam, M.S., Jamil, M.R., Chowdhury, M.N., Kabir, M.H. and Rimi, R.H. 2020. Impact of cyclone and flood on crop and fish production in disaster prone coastal Bhola district of Bangladesh. Int. J. Agril. Res. Innov. Tech. 10(1): 40-55. https://doi.org/10.3329/ijarit.v10i1.48093

\section{Introduction}

Climate change refers to a change in the state of the climate that can be identified (e.g., by using statistical tests) by changes in the mean and/or the variability of its properties and that persists for an extended period, typically decades or longer (IPCC, 2007; IPCC, 2012). It is one of the most disputed global issues and considered as a prominent example of a negative environmental externality (Tol, 2009). Temperature rise, warming oceans, sea level rise, extreme events, ocean acidification are the major manifestation of climate change. Climate change is likely to hamper agricultural production in coming decades, particularly in low-income countries where adaptive capacity is limited. Consequently, farmers are losing their interest in rice and other winter crop cultivation due to recurrent natural calamities (Neogi and Erskine, 2017).

In Bangladesh population growth rate is 2 million per year, and with such a growth rate, the population will become 233.2 million by 2050 (Basak, 2010). To meet the demands of its growing population, an estimated $70 \%$ increase in rice production is required over the coming decades (IRRI, 1993). In Bangladesh 90\% of the rural population are directly related to 
agricultural activities. Agriculture sector contributes to income and employment generation in Bangladesh (MoEF, 2009). The Agro-economic contribution is $20.83 \%$ of the Gross Domestic Product (GDP). The coastal region plays a vital role in the national economy. Agricultural crops are being influenced by seasonal characteristics and distinct climate variables such as temperature, rainfall, humidity and day- length (Gornall et al., 2010). Bangladesh is one of the most vulnerable countries to climate change because of its geographic location; flat and low lying topography; high levels of poverty; reliance of many livelihoods that are sensitive to climate change particularly agriculture and fisheries (CCC, 2009). Natural disasters such as flood, droughts, soil and water salinity, cyclone, storm surges etc. affect crops and fisheries production. Several studies indicated that climate is changing and becoming more unpredictable every year in Bangladesh (Basak, 2010; Kotir, 2011). For instance, two rounds of floods and devastating cyclone Sidr in 2007 and cyclone Aila in 2009 and other recurrent natural disasters caused intense damage in agricultural production (Basak, 2010).

The two upazilas namely Bhola Sadar and Manpura of coastal Bhola district are affected by several climatic hazards, so this area is referred to as the coastal tidal surge prone area (MoEF, 2009). Here almost every year, crops and fish production are hampered due to some climatic hazards. The main sources of income of this area include agriculture (63.91\%) followed by fisheries production and fish export, especially Hilsha fish. Major crops are paddy, chili, wheat, mung bean, sweet potato, ground nut, betel nut, betel leaf and masur, whereas, extinct or nearly extinct crops are tobacco, jute, linseed and sugarcane (NDP, 2013). Bhola district struggles to provide sufficient food for a population over 17 million due to agricultural and fisheries damage and loss of production (Banglapedia, 2017).

Due to climate change and human activities, the river tends to erode and a number of locations face severe bank-erosion problem. However, the effects of climate change are already evident on the agro-ecosystem, agriculture and fisheries production at Bhola district. The purpose of the study was to assess the impacts of climate change on crop and fisheries production and aimed to: i) assess climate change associated natural disasters, ii) both past and present crop and fish production status, and iii) identify impacts of climate change induced disaster on crops and fisheries production.

\section{Materials and Methods}

\section{Study area}

The study was carried out in two upazila including Bhola Sadar (Kachia union) and Manpura (Manpura union) of Bhola district (Fig. 1). These two upazilas are situated in between $22^{\circ} 41^{\prime} 24.65^{\prime \prime} \mathrm{N}$ and $22^{\circ} 11^{\prime} 59.24^{\prime \prime} \mathrm{N}$ latitude to $90^{\circ} 37^{\prime} 13.50^{\prime \prime} \mathrm{E}$ and $90^{\circ} 57^{\prime} 13.49^{\prime \prime} \mathrm{E}$ longitude. The two unions under the two upazilas are selected for being extremely vulnerable to natural disasters like floods, cyclones, tidal surges, tornadoes, river erosion and salinity intrusion. River floods are the most common over here. Areas are frequently flashed out by tidal water and inundated during monsoon season (Banglapedia, 2017).

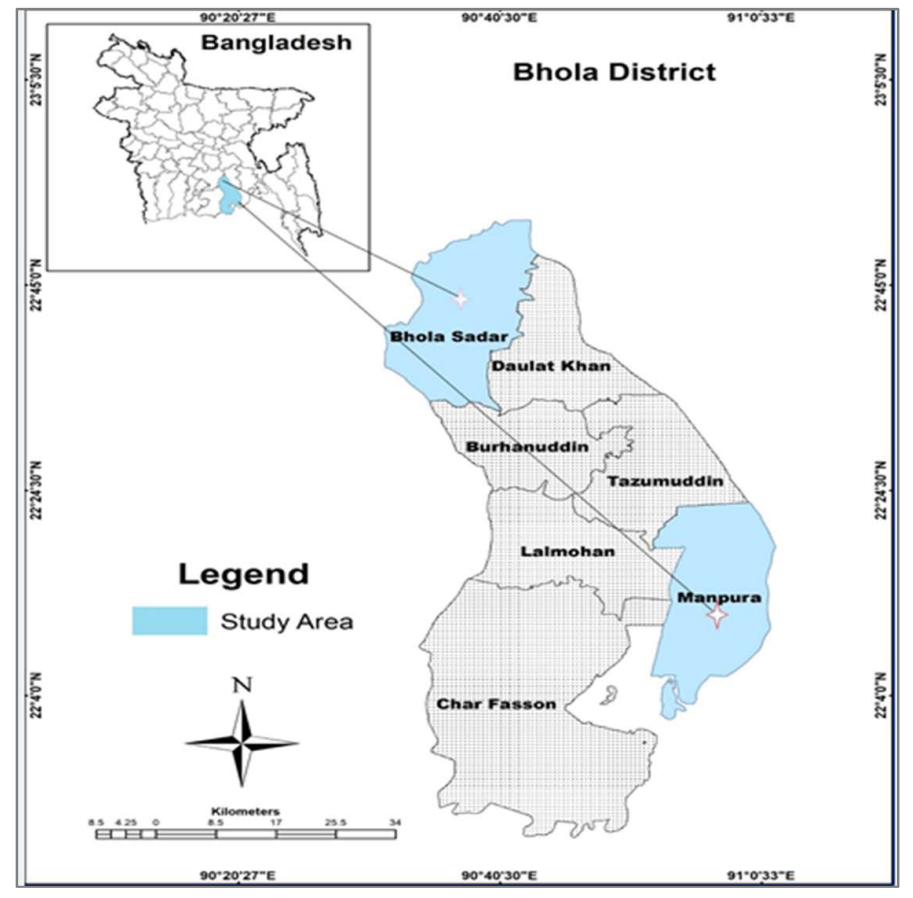

Fig. 1. Map showing the location of study area in Bhola Sadar and Manpura Upazila of Bhola district, Bangladesh. 


\section{Data collection, processing and analysis}

Data collection is the systematic process to gather and measure information from a variety of sources to get overall and accurate idea of an area of interest (Fig. 2). For this study, primary data was collected through observation, questionnaire survey, key informant interview (KII) and focus group discussion (FGD). The KIIs typically involved a one-on-one conversation between a research team member and a key informant. Questionnaire survey was carried out in two upazilas with 100 respondents who provided their perception about climate change impact on crop and fisheries production. The FGD involved 100 respondents from each union, which included 5 experts, 70 different professions living in disaster prone area, and 25 others. Secondary data for agriculture, fisheries, and disasters were collected from archives of government and nongovernment organizations and institutions, diaries, reports, related journals, and papers. The crop and fish production was measured in the unit of metric tons (MT). All data were processed and analyzed by using MS excel, Minitab, and SPSS software.

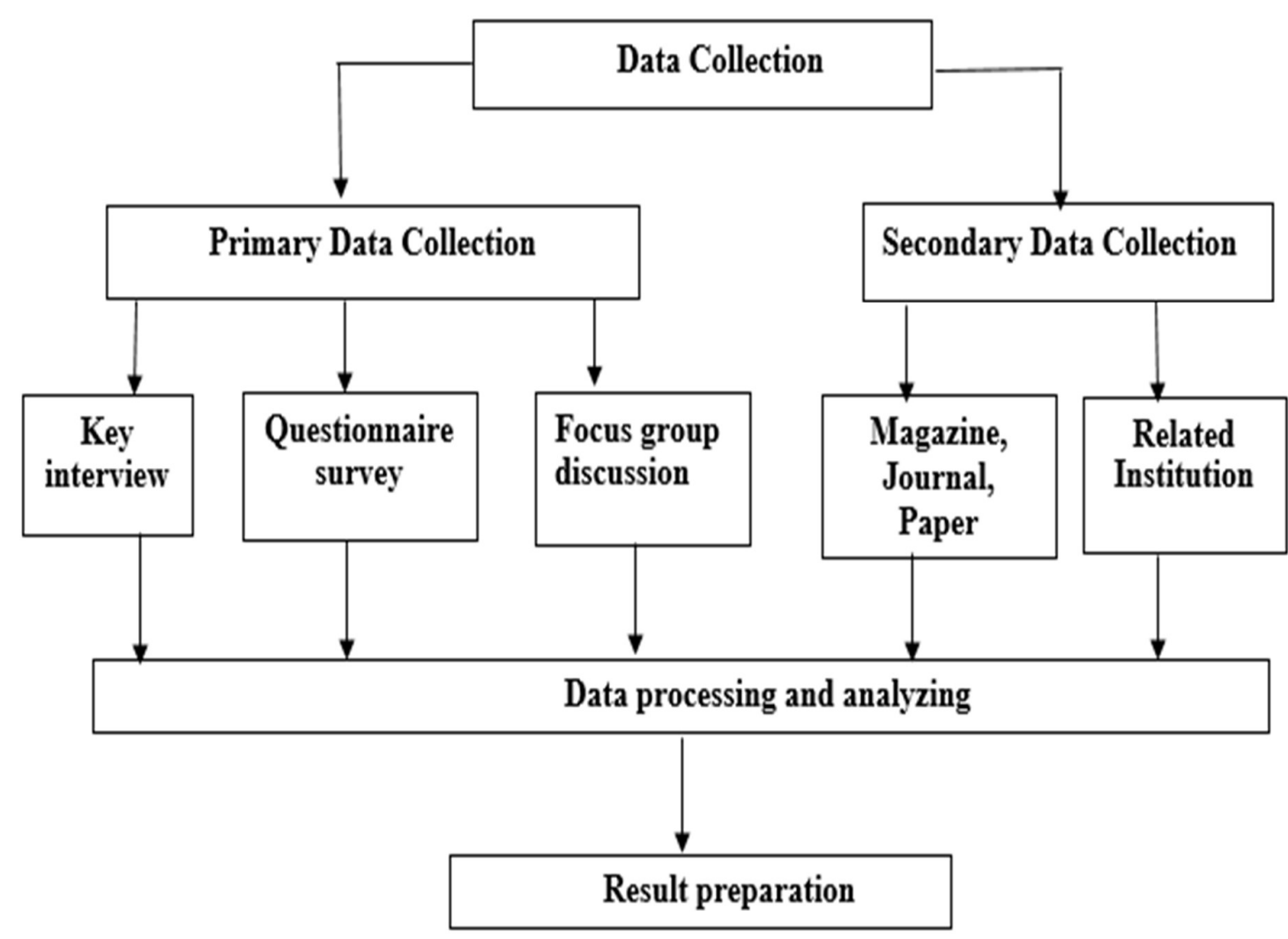

Fig. 2. The data collection process in the study area of Bhola district.

\section{Results and Discussion}

\section{People's perception on climatic hazards}

Changes of climatic variables: The study found $86 \%$ of the respondents think that temperature is increasing, while $14 \%$ people provided no answer.
Only $2 \%$ of the respondents think that rainfall is increasing, but majority (78\%) of them believed that rainfall is decreasing (Fig. 3). No one understood what humidity is and they did not give any answer. 


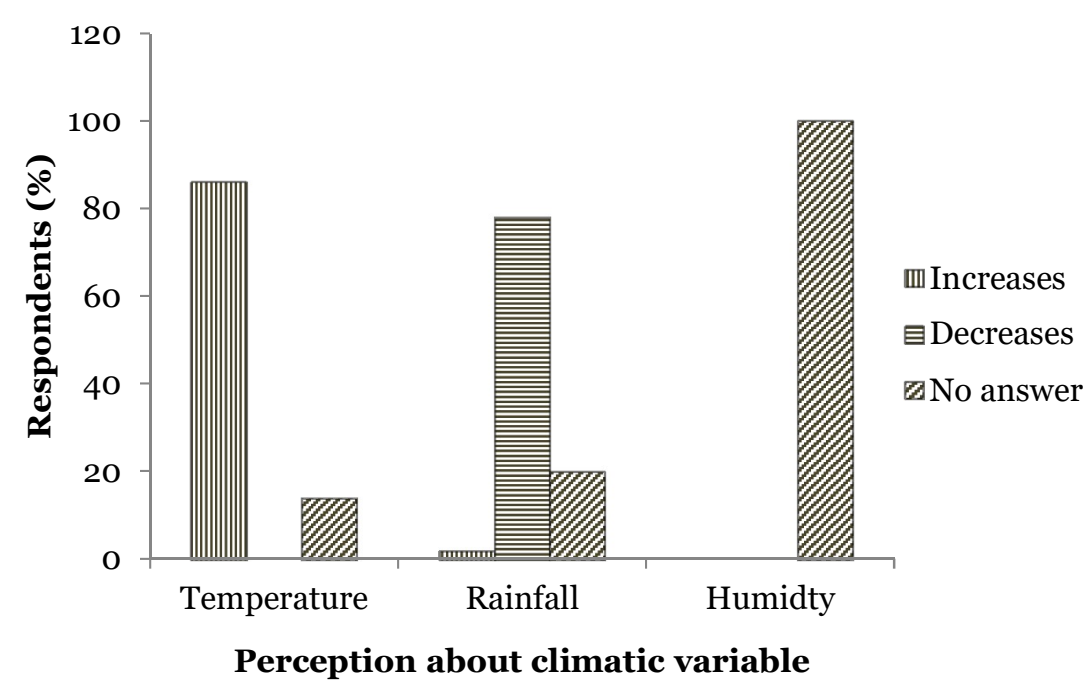

Fig. 3. Perception of the respondent's about climatic variable.

Impact of natural disaster: The main natural disasters in Bhola district include flood, storm, cyclone and salinity intrusion. The frequency of flood decreased but the intensity increased significantly (Karim, 2010; DMB, 2010). Due to geographical location, Bangladesh receives and drains out huge volume of upstream waters. Consequently, frequent floods cause devastating effects on people's livelihoods. In the rainy season, saline water ingress up to $10 \%$ of inland area, while in the dry season saline water reaches up to $40 \%$ inland area (Shamsuddoha and Chowdhury, 2007). According to the survey, 15\% of the respondents said that salinity is increasing, whereas $16 \%$ identified river erosion as the severe natural disaster. On the other hand, $28 \%$ and $37 \%$ of the respondents think that flood and cyclone are the main disaster, respectively. Only 3\% respondents mentioned about drought (Fig. 4).

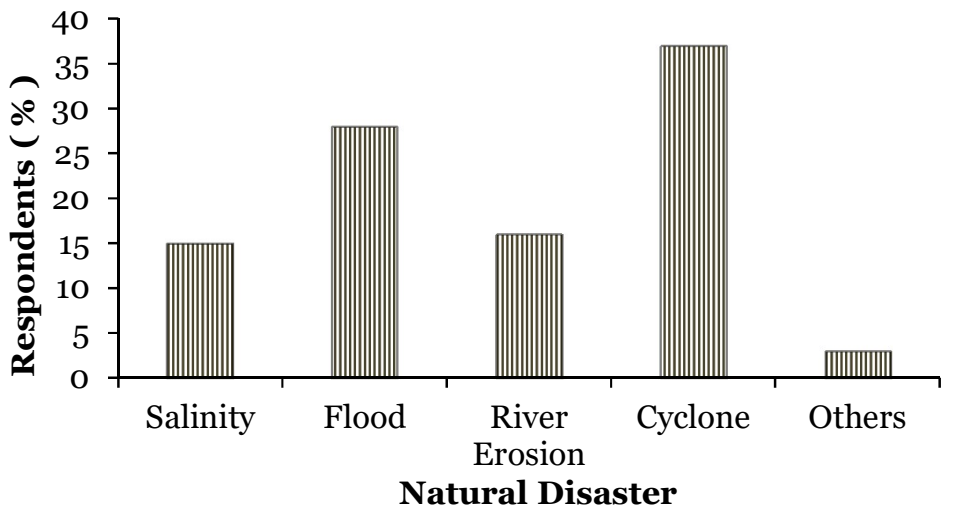

Fig. 4. Perceptions of respondent on natural disaster.

Impacts on livelihood: The 53\% of the respondents said climate change has impacts on their livelihoods, $17 \%$ of them said it has no impacts, but 30\% had no idea of impacts (Fig. 5). In Bhola $71 \%$ farms were affected by flood and $12 \%$ stored grains were damaged in 2009 flood
(Hasan et al., 2014). Safety and injuries at sea are often associated with natural disasters such as floods and hurricanes, reducing the physical abilities of fisher folk to continue their livelihoods (Badjeck et al., 2010). 


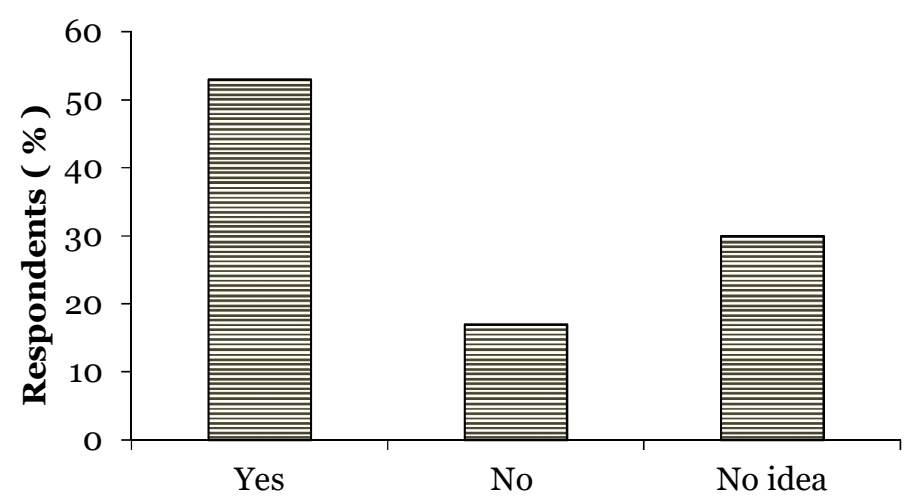

Climatic Impact

Fig. 5. Perception on climate change impact on people's livelihood.

Trend analysis: This section describes the seasonal trend of climatic variability (average temperature, humidity and rainfall for Kharif-I, Kharif-II, and Rabi season) in the southern Bhola district of Bangladesh. For Kharif-I season cover the time duration from (mid March-mid July), Kharif-II season time duration (mid July-mid November) and Rabi season cover (mid November- mid March) (Islam et al., 2019).

Trend of average annual maximum temperature of the study area: It was revealed that maximum temperature was increasing with $0.04^{\circ} \mathrm{C}$ per year in Kharif-I season. For Kharif-I season, the value of R2=0.44 means the variables are moderately fitted in the regression line. Study also found an increasing trend and the rate was $0.028^{\circ} \mathrm{C}$ per year in the time span for Kharif-II. In Rabi season, maximum temperature trend indicate temperature rises with $0.015^{\circ} \mathrm{C}$ per year within time period between 1990 and 2019 in our study area (Fig. 6). Shahid (2010) reported that average maximum temperature in Bhola increases $0.12^{\circ} \mathrm{C}$ per decade.

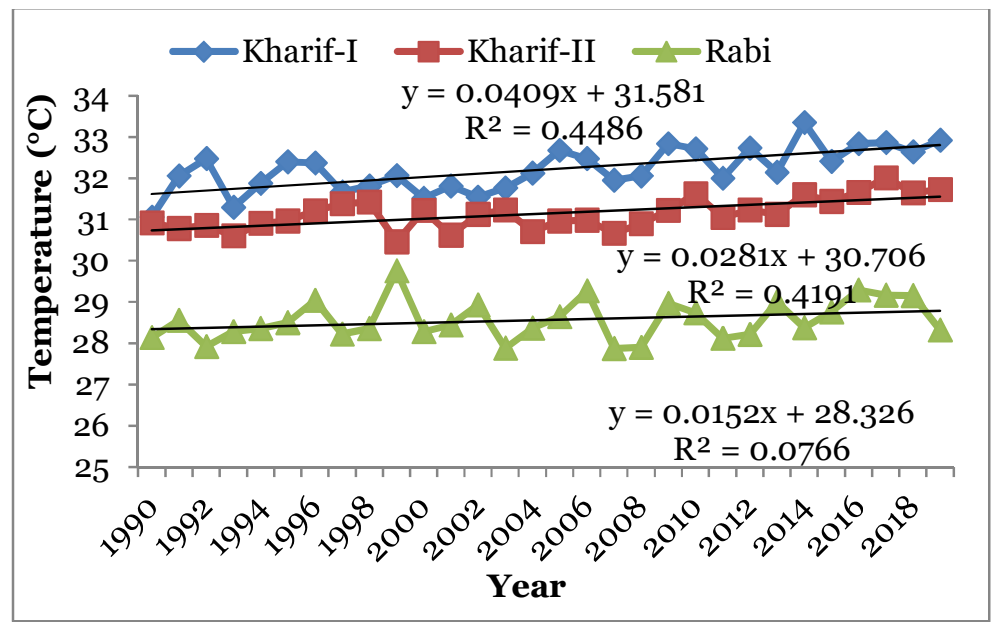

Fig. 6. Maximum temperature in Kharif-I, Kharif-II and Rabi season (1990-2019).

Trend of average annual minimum temperature of the study area: The trend of average minimum temperature exhibited an increasing trend with $0.009^{\circ} \mathrm{C}$ per year from (1990-2019) for Kharif-I season, the value of $\mathrm{R}^{2}=0.03$ means the variables are very slightly fitted in the regression line. For Kharif-II season average minimum temperature are decreases $0.0044^{\circ} \mathrm{C}$ per year and in Rabi season average minimum temperature decreases $0.014^{\circ} \mathrm{C}$ per year in the $1990-2019$ time period. Highest change of monthly average minimum temperature was found for Northern region in Bangladesh for maximum months, whereas lowest change for Southeastern region during the period of (1976-2008) (Basak et al., 2013).

Trend of average annual relative humidity of the study area: Average humidity trend from (19902019) exhibited a decreasing trend with $0.13 \%$ per for Kharif-I season, the value of $\mathrm{R}^{2}=0.48$ means the variables are moderately fitted in the regression line. For Kharif-II season average humidity are decreases over time period 19902019 at the rate of $0.094 \%$ per year. The value of $\mathrm{R}^{2}=0.427$ means the variables are moderately fitted in the regression line and in Rabi season 
average minimum temperature are decreases 0.061\% per year in the 1990-2019 time periods (Fig. 7). According to Rajib et al. (2011), humidity showed increasing trends in almost all the parts of Bangladesh except that the south west region which showed decreasing trend. It decreased up to $0.16 \%$.

Trend of annual average rainfall of the study area: In Kharif-I and Rabi seasons the trend of average rainfall exhibited a decreasing trend with 1.07 and $1.18 \mathrm{~mm}$ per year in last thirty years but in Kharif-II season overall rainfall rates were increased in the (1990-2019) time period (Fig. 8). A study by Shahid (2010) found that changes in precipitation over Barisal increased at the rate of $0.89,1.23 \mathrm{~mm}$ in monsoon and pre-monsoon season and decreased at the rate of $0.45 \mathrm{~mm}$ per year post-monsoon season from (1958-2007) time period. Rimi et al. (2009) reported that the overall climate scenario exhibited an increasing trend of total annual rainfall at Satkhira, which was not statistically significant.

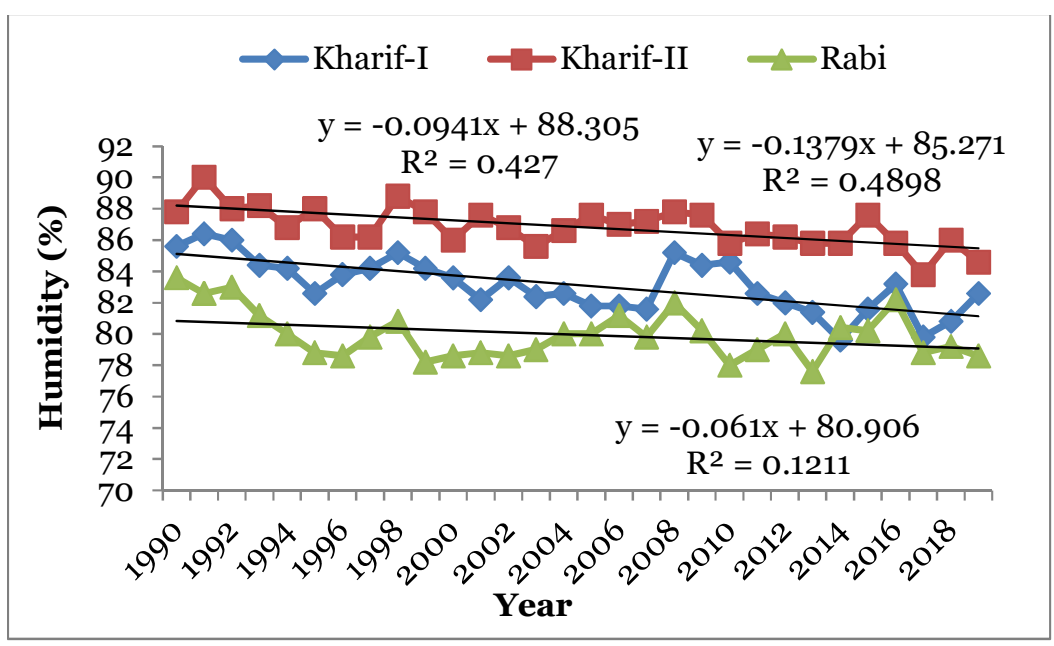

Fig. 7. Annual average humidity in Kharif-I, Kharif-II, and Rabi season (1990-2019).

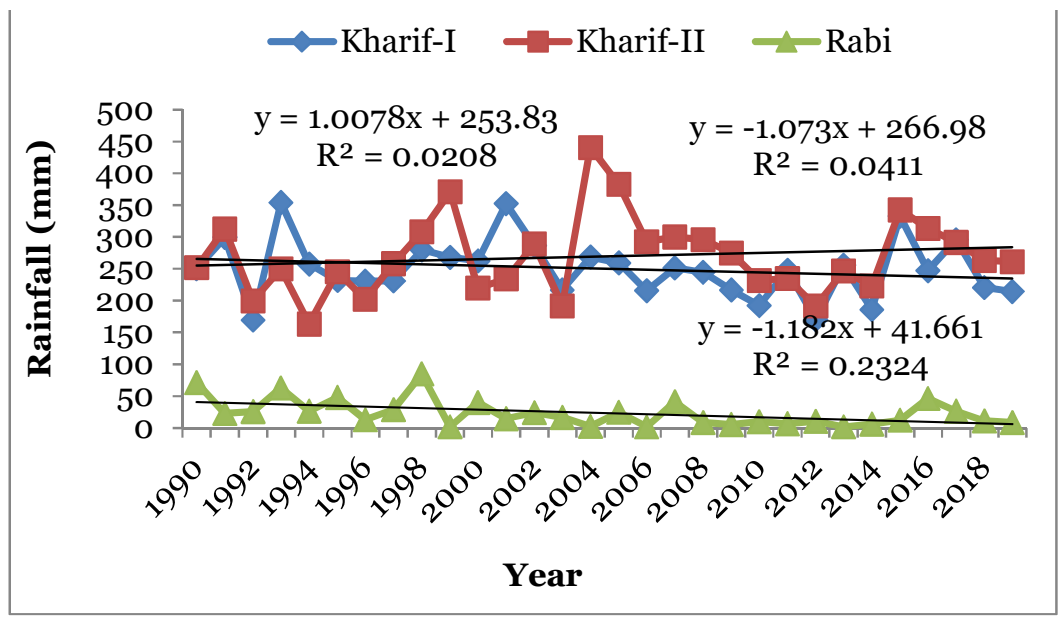

Fig. 8. Annual average rainfall in Kharif-I, Kharif-II, and Rabi season (1990-2019).

\section{Major natural disaster}

Bangladesh experienced 224 natural disasters between 1980 and 2018, causing damage of over US \$ 16 billion (UNDP, 2006).This study found that cyclones and floods are the most common natural disasters in Bhola district (Table 1). The catastrophic disasters between 2007 and 2018 in the study area are cyclone Sidr (2007), cyclone Aila (2009), cyclone Mahasen (2013) followed by other cyclones and floods. In 2007, most of the destructive flood causing more than 800 deaths
(DMB, 2010). Cyclone Sidr stroked on 15 November 2007 with $250 \mathrm{~km} \mathrm{hr}^{-1}$ wind speeds and a five-meter sea surge, killing more than 3300 people. Cyclone Aila hit on Monday 25 May 2009 and caused substantial damage across areas of southern Bangladesh with 190 immediate deaths. Cyclone Mahasen stroked on $16^{\text {th }}$ May 2013 and affected 8 coastal districts including Chittagong, Bhola, Barguna, Pirojpur, Noakhali, Patuakhali, Satkhira and Laxmipur (Rahman et al., 2107) and caused severe damage of lives and properties. 
Table 1. Natural disaster occurred in the study area.

\begin{tabular}{|c|c|c|c|c|c|}
\hline Year & Disasters & $\begin{array}{l}\text { Month of } \\
\text { occurrence }\end{array}$ & Affected district & $\begin{array}{l}\text { Affected } \\
\text { locations of } \\
\text { Bhola district }\end{array}$ & $\begin{array}{l}\text { Observed devastating } \\
\text { features }\end{array}$ \\
\hline 2007 & $\begin{array}{l}\text { Cyclone } \\
\text { Sidr }\end{array}$ & $\begin{array}{l}15^{\text {th }} \\
\text { November }\end{array}$ & $\begin{array}{l}\text { SIDR has affected } \\
\text { some } 22 \text { districts of } \\
\text { the country. The } \\
\text { most } \quad \text { seriously } \\
\text { affected districts are } \\
\text { the coastal districts } \\
\text { of Barguna, } \\
\text { Patuakhali, Bagerhat, } \\
\text { Barisal, Bhola, } \\
\text { Pirojpur, Satkhira, } \\
\text { Khulna, and } \\
\text { Jhalakati. }\end{array}$ & $\begin{array}{l}\text { All upazila of } \\
\text { Bhola district } \\
\text { was affected but } \\
\text { Charfesson } \\
\text { upazila } \\
\text { comparatively } \\
\text { mostly affected. }\end{array}$ & $\begin{array}{l}\text { Heavy rain } \\
\text { accompanying } \\
\text { cyclones and tidal } \\
\text { waves due to wind } \\
\text { effects caused } \\
\text { extensive physical } \\
\text { destruction, damage } \\
\text { of crops and fisheries } \\
\text { by inundation of low } \\
\text { land areas and } \\
\text { ponds. }\end{array}$ \\
\hline 2009 & Aila & $25^{\text {th }}$ May & $\begin{array}{l}\text { Satkhira and Khulna } \\
\text { districts } \\
\text { Bangladesh suffered } \\
\text { the severed damage } \\
\text { along with Bagerhat, } \\
\text { Pirojpur, Barisal, } \\
\text { Patuakhali, Bhola, } \\
\text { Lakshmipur, } \\
\text { Noakhali, Feni, } \\
\text { Chittagong, and } \\
\text { Cox's Bazar. }\end{array}$ & $\begin{array}{l}\text { Bhola district } \\
\text { comparatively } \\
\text { less affected than } \\
\text { Khulna district. } \\
\text { Though } \\
\text { Daulatkhan, } \\
\text { Charfesson and } \\
\text { Monpura Upazila } \\
\text { faced heavy } \\
\text { losses of crop } \\
\text { production. }\end{array}$ & $\begin{array}{l}\text { It caused about } 190 \\
\text { human deaths on } \\
\text { coastal areas people. } \\
\text { A heavy loss of } \\
\text { livestock's as well as } \\
\text { standing crops on } \\
\text { vast tracts of land } \\
\text { were smashed. Such } \\
\text { kind of frequent } \\
\text { climatic events } \\
\text { severely affected } \\
\text { agricultural land and } \\
\text { caused of changed } \\
\text { the land use pattern. }\end{array}$ \\
\hline 2013 & Mahasen & $16^{\text {th }}$ May & $\begin{array}{l}\text { This tropical Cyclone } \\
\text { mostly affected in } \\
\text { Barguna, Patuakhali, } \\
\text { Bhola, and } \\
\text { Chittagong. }\end{array}$ & $\begin{array}{l}\text { Low lying areas } \\
\text { of Monpura, } \\
\text { Charfesson, } \\
\text { Daulatkhan and } \\
\text { Bhola sadar } \\
\text { upazila under } \\
\text { Bhola districts } \\
\text { were inundated } \\
\text { by 1-2 feet water. }\end{array}$ & $\begin{array}{l}\text { Crop losses in the } \\
\text { Barisal division } \\
\text { amounted to taka } 40 \\
\text { crore more than half } \\
\text { occurring in } \\
\text { Charfesson } \\
\text { Bhola alone. }\end{array}$ \\
\hline 2014 & Flood & $\begin{array}{l}\text { July and } \\
\text { August }\end{array}$ & $\begin{array}{l}\text { Kurigram, } \\
\text { Gaibandha, } \\
\text { Lalmonirhat, } \\
\text { Sirajganj, Bogura, } \\
\text { Rangpur, Jamalpur, } \\
\text { Nilphamari, Bhola, } \\
\text { and Sherpur. }\end{array}$ & $\begin{array}{l}\text { Bhola Sadar, } \\
\text { Monpura, } \\
\text { Charfesson and } \\
\text { Daulatkhan } \\
\text { Upazilas. }\end{array}$ & $\begin{array}{l}\text { More than } 30,000 \\
\text { people had been } \\
\text { marooned as tidal } \\
\text { water broke through } \\
\text { dykes in Monpura, } \\
\text { Daulatkhan and } \\
\text { Tazumuddin upazilas } \\
\text { and some crops in } \\
\text { Kharif-II season } \\
\text { washed away. }\end{array}$ \\
\hline 2017 & Flood & June & $\begin{array}{l}\text { Kurigram, } \\
\text { Nilphamari, } \\
\text { Lalmonirhat, } \\
\text { Jamalpur, Tangail, } \\
\text { Manikgonj r and } \\
\text { Gaibandha, Bhola, } \\
\text { Barisal. }\end{array}$ & $\begin{array}{l}\text { Monpura, Bhola } \\
\text { Sadar, } \\
\text { Charfesson and } \\
\text { Daulatkhan. }\end{array}$ & $\begin{array}{l}\text { Parts of the Ilisha, } \\
\text { Kachia, in Bhola } \\
\text { Sadar upazila had } \\
\text { been damaged by the } \\
\text { depression-triggered } \\
\text { tidal pressure. The } \\
400 \text { hectors of low } \\
\text { land areas was } \\
\text { inundated by flood. }\end{array}$ \\
\hline 20018 & Flood & July & $\begin{array}{l}\text { Sylhet, Sunamgonj, } \\
\text { Habiganj, Kurigram, } \\
\text { Nilphamari, Sherpur, } \\
\text { Jamalpur, Bhola. }\end{array}$ & $\begin{array}{l}\text { Tazumuddin, } \\
\text { Monpura, Bhola } \\
\text { Sadar and } \\
\text { Charfesson } \\
\text { upazilas. }\end{array}$ & $\begin{array}{l}\text { Low lying crops land } \\
\text { and pond were } \\
\text { drowned by flood and } \\
\text { T. Aman rice } \\
\text { cultivation in Kharif- } \\
\text { II season being late } \\
\text { to cultivation. }\end{array}$ \\
\hline
\end{tabular}

Source: Banglapedia, 2017; Disaster and Relief Office, Bhola district, Bangladesh (2018). 


\section{Cropping pattern}

A spatial and temporal arrangement of crops within a cropping year, largely determined by physical, biological, and socioeconomic factors. Bangladesh has three cropping seasons (Rabi, Kharif-I and Kharif-II) in a year (Table 2). Since rice is the major crop, it dominates the cropping pattern. In medium lowlands, mixed cropping of Aus and broadcast Aman is a common practice, while in deeply flooded lands, single cropping of broadcast Aman (deep water rice) in Kharif or Boro in Rabi is the common practice. Most of the farmers focus or practice sequential cropping and mixed cropping. Different varieties of pulses, vegetables practices are taking place instead of Boro rice. Study found Boro cultivation occurred in Bhola Sadar Upazila. But In Monpura upazila Boro cultivation replaced by vegetables and Mung bean because of soil salinity and low rainfall.

Table 2. The existing cropping pattern in Bhola Sadar and Manpura Upazila.

\begin{tabular}{|c|c|c|c|c|c|}
\hline \multirow{2}{*}{ Upazila } & \multirow{2}{*}{ Crop land } & \multicolumn{3}{|c|}{ Cropping pattern } & \multirow{2}{*}{ (\%) } \\
\hline & & Rabi & Kharif-I & Kharif-II & \\
\hline \multirow{9}{*}{$\begin{array}{l}\text { Bhola } \\
\text { Sadar }\end{array}$} & \multirow{5}{*}{ Triple crop } & Boro & Aus & T. Aman & 10 \\
\hline & & Wheat & Aus & T. Aman & 5 \\
\hline & & Chili & Aus & T. Aman & - \\
\hline & & Mung bean & Aus & T. Aman & 10 \\
\hline & & Winter vegetable & Aus & T. Aman & 10 \\
\hline & \multirow{3}{*}{ Double crop } & Boro & Fallow land & T. Aman & 15 \\
\hline & & Winter vegetable & Fallow land & T. Aman & 25 \\
\hline & & Mung bean & Fallow land & T. Aman & 25 \\
\hline & Single crop & Fallow land & Fallow land & T. Aman & - \\
\hline \multirow{8}{*}{ Monpura } & \multirow{4}{*}{ Triple crop } & Mung bean & Aus & T. Aman & 5 \\
\hline & & Potato & Aus & T. Aman & 15 \\
\hline & & Soybean & Aus & T. Aman & - \\
\hline & & Chili & Aus & T. Aman & - \\
\hline & \multirow{3}{*}{ Double crop } & Mung bean & Fallow land & T. Aman & 25 \\
\hline & & Vegetable & Fallow land & T. Aman & 30 \\
\hline & & Maize & Fallow land & T. Aman & 5 \\
\hline & Single crop & Fallow land & Fallow land & T. Aman & 5 \\
\hline
\end{tabular}

Note: T. Aman = Transplanted Aman, Source: DAE, Bhola Sadar and Manpura, Bhola district, Bangladesh (2018).

\section{Crop production}

Aus production in Bhola Sadar: According to Rashid and Islam (2007) droughts, floods, soil salinity and cyclones are the major climatic events that have affected agricultural production adversely. The highest production of Aus rice $(12,990$ MT) was seen in $2017-2018$ and the lowest (6,236 MT) was found in 2006-2007 (Fig. 9). Cyclone Aila, Mahasen and flash flood in 2009, 2013 and 2017 hampered Aus rice production. However, Aus production is increasing over time because of introduction of saline tolerant seeds and high yielding varieties.

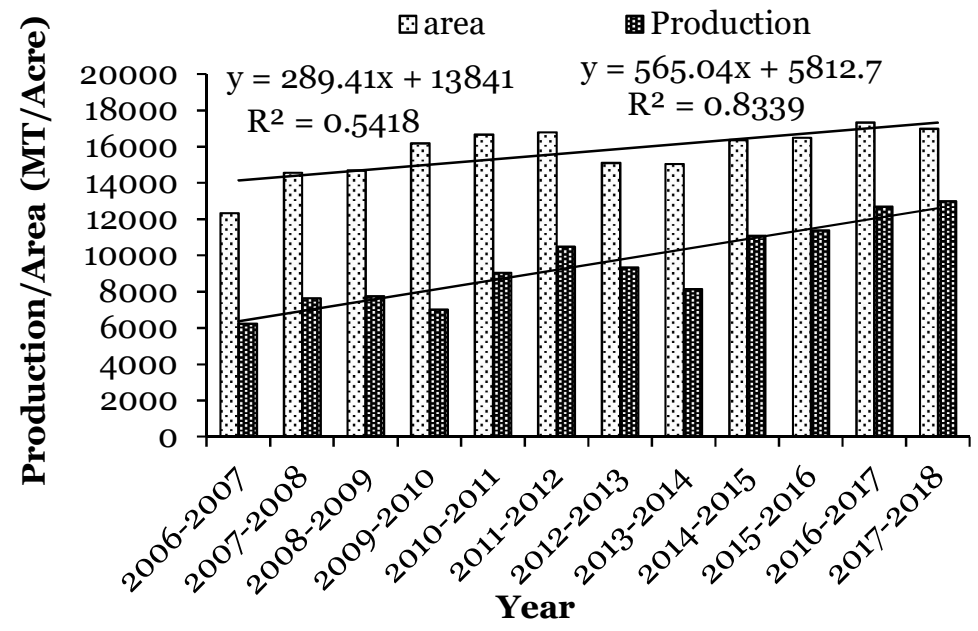

Fig. 9. Aus rice production in Bhola Sadar from 2006-2017. 
Aus production in Manpura: The highest and lowest Aus production was seen in 2016-2017 and 2006-2007 with 10,523 and 4,988 MT (Fig. 10). Because of 2005 flood most of the lands were affected and this in turn the lowest productions. Less Aus production was found in 2009 and 2017 due to Cyclone Aila and flash flood though other year's production was high.

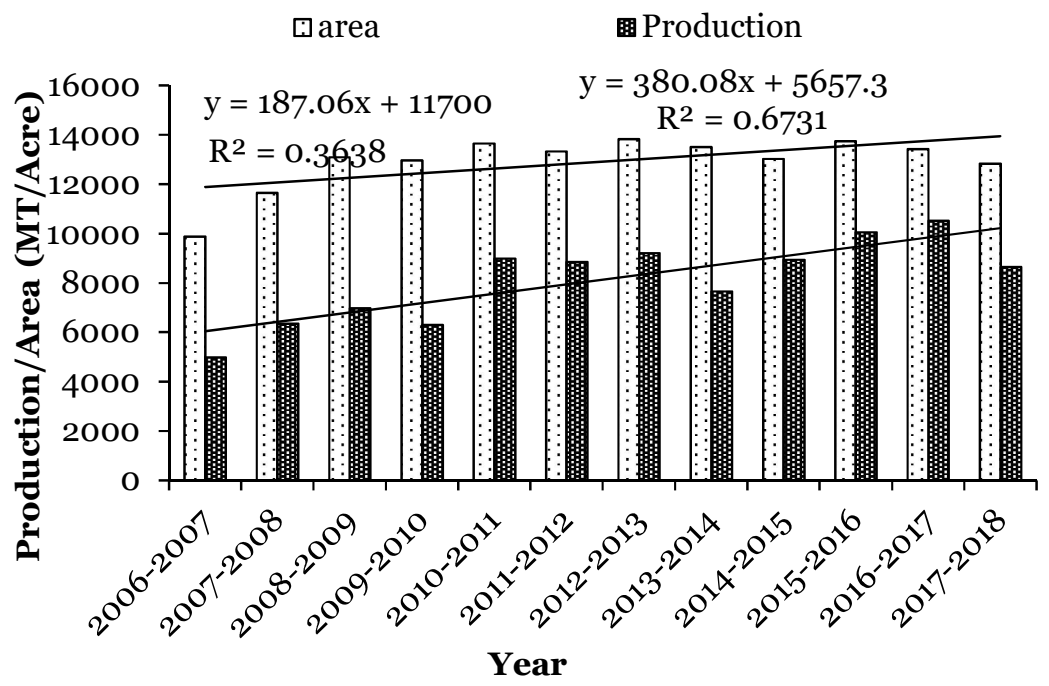

Fig. 10. Aus rice production in Manpura Upazila from 2006-2017.

Aman production in Bhola Sadar: The highest production of Aman rice was in 2016-2017, amounting to 21,925 MT, while the lowest production of 15,678 MT was in 2008-2009 (Fig.
11). Cyclone Sidr of 2007 significantly reduced rice productions in 2008-2009. In 2014, Aman cultivation becomes less because of flood.

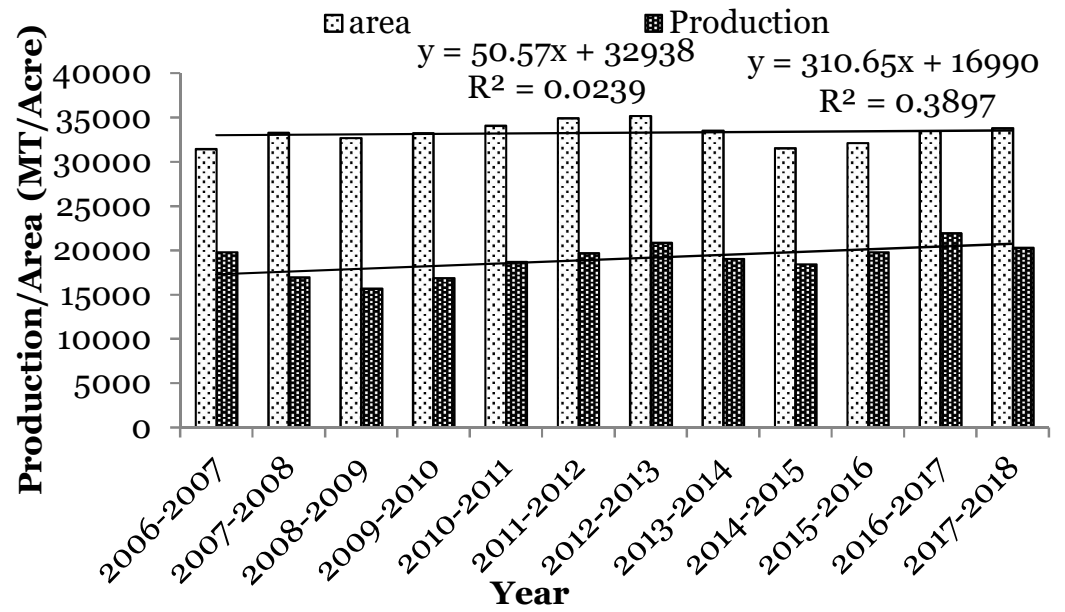

Fig. 11. Aman rice production in Bhola sadar Upazila from 2006-2017.

Aman production in Manpura: The maximum production of Aman rice (18,845 MT) was found in 2016-2017 and lowest production of Aman (14,135 MT) was seen in 2008-2009 (Fig. 12).
Due to cyclone Sidr (2007), production was reduced significantly in 2008-2009. Flood in 2014 also caused of less production in 2014-2015. 


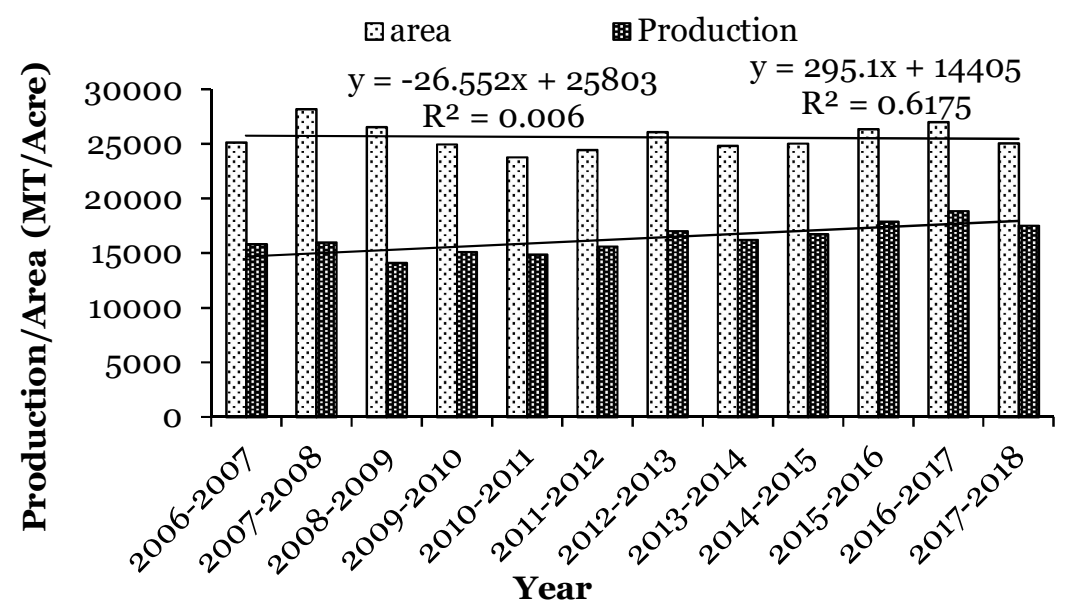

Fig. 12. Aman rice production in Manpura Upazila from 2006-2017.

Boro production in Bhola Sadar: The highest in 2007-2008 amounting 16,035 MT and characteristics of floodwater may be hampering the lowest (11,089 MT) was in 2017-2018 (Fig. Boro rice production. Instead of depositing silt 13). Low average rainfall especially in Rabi season that boosts soil fertility, floodwaters are now caused of less amount of Boro rice cultivation and carrying more sands, which often turn the whole production.

fields unusable for agricultural production (Chowdhury, 2002). Boro rice production was

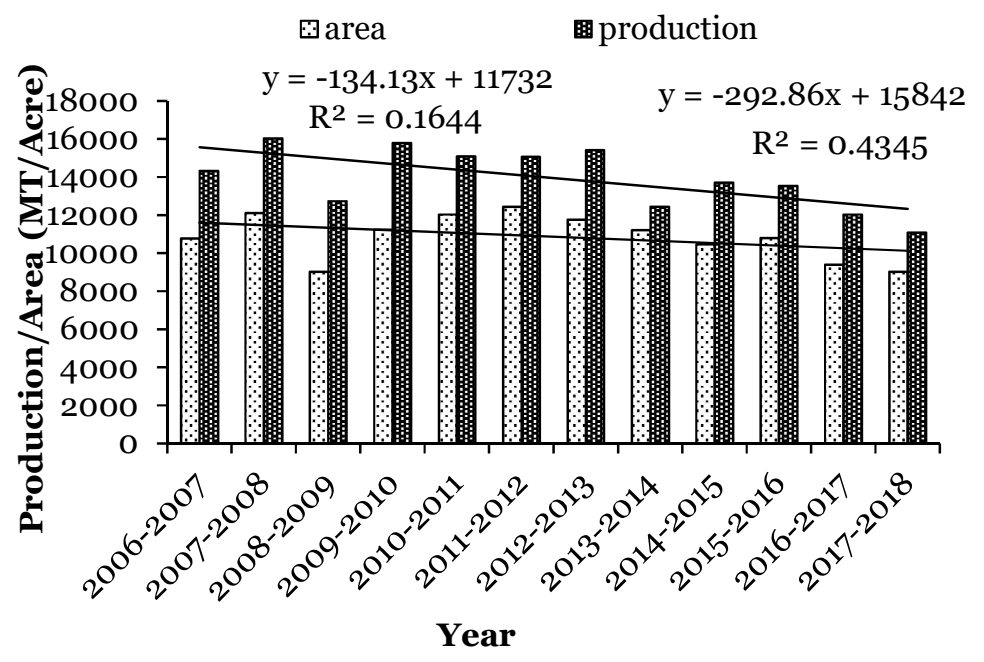

Fig. 13. Boro rice production in Bhola Sadar Upazila from 2006-2017.

Mung bean production in Bhola Sadar: The maximum (23,430 MT) Mung bean production was found in 2014-2015 and lowest (19,350 MT) production was found in 2007-2008 (Fig. 14).
The cyclone Sidr (2007) was responsible for the reduction in production. Overall, there is an increasing trend of Mung bean production during 2006-2017. 


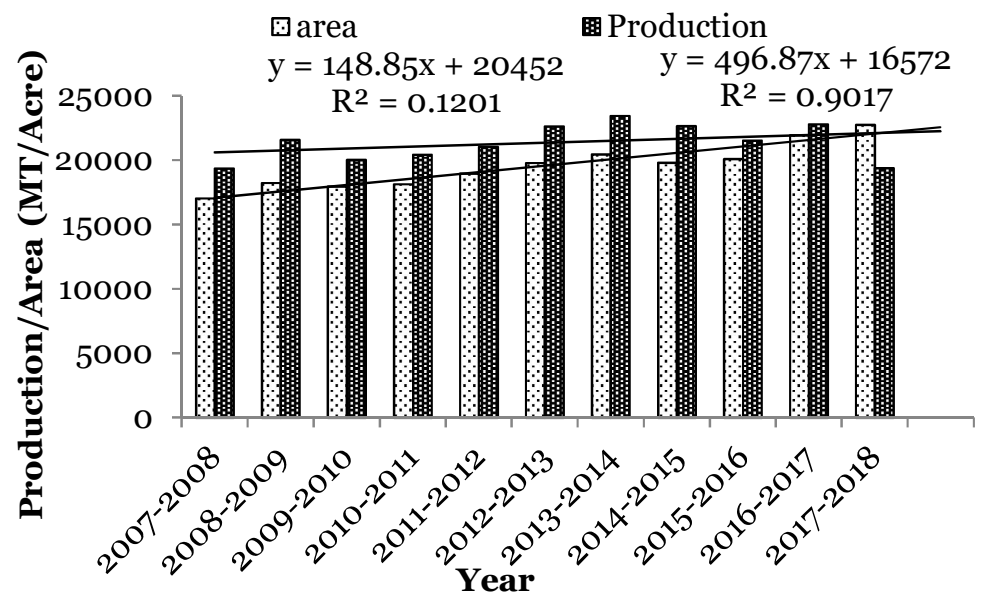

Fig. 14. Mung bean production in Bhola Sadar Upazila from 2006-2017.

Mung bean production in Manpura: The Mung bean production was found to be highest $(18,240$ MT) in 2015-2016. The lowest (12,612 MT) production was found in 2009-2010 (Fig. 15). Due to cyclone Sidr and Aila in 2007 and 2009, the Mung bean crops was being late cultivated that caused of delayed to next crop cultivation and caused reduction of production. Farmers cultivated Mung bean or vegetables instead of Boro rice. More water was required in Boro cultivation but due to less rainfall and salinity in Rabi season high yield Mung bean varieties replaced Boro cultivation especially in Monpura Upazila of Bhola district.

\section{Impact on crop production:}

According to the study, 91\% of the respondents said production increased because of high yielding varieties, fertilizer practice, pesticides use and mixed cropping pattern, etc. Only $3 \%$ said production decreased and 6\% said that production was same as before (Fig. 16).

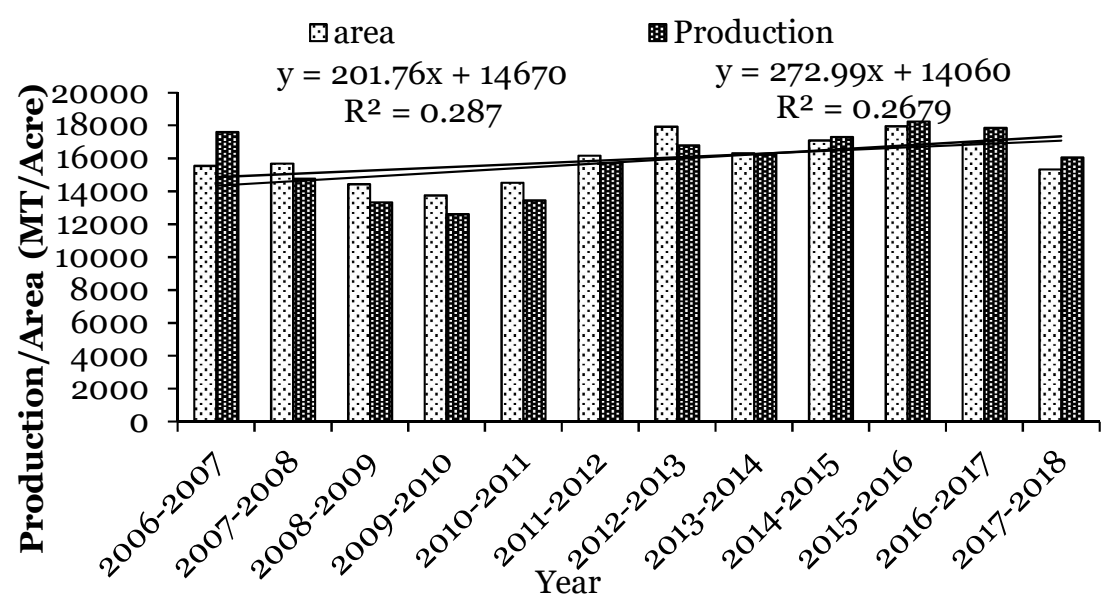

Fig. 15. Mung bean production in Manpura Upazila from 2006-2017. 


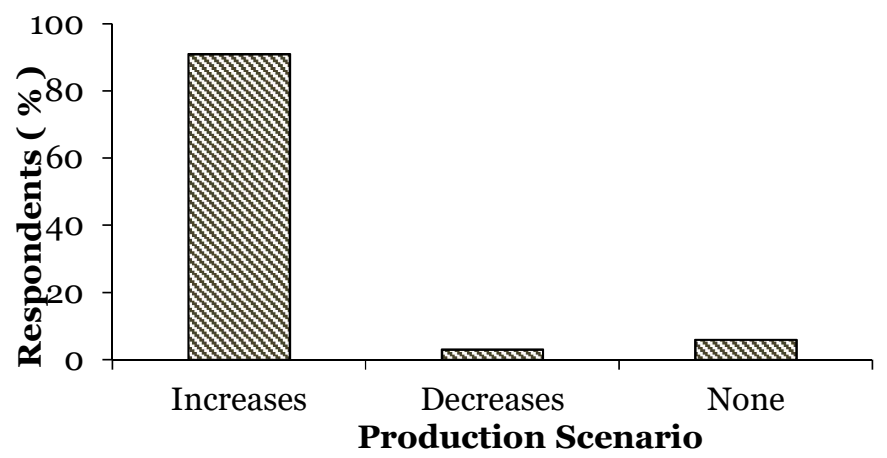

Fig. 16. Crop production scenario.

Causes of increasing crop production: The $45 \%$ of the respondents believe that production was increased due to high yielding varieties, $22 \%$ said use of fertilizer in proper amount, $13 \%$ believe climatic condition is friendly for production, $12 \%$ mentioned about modern technologies and 8\% said there were other reasons like training, incentives and high yield crop seed provided by NGO and government behind the increase in production (Fig. 17).
According to FGD, farmers cultivated mainly 4 types of crops, local Aus, Aman, Boro and Mung bean. Farmers and fisherman said their crop and fish production is increasing. But, Boro rice production is decreasing due to salinity intrusion and less rainfall. According to KII, salinity intrusion is increasing and low average rainfall in Bhola district caused of Boro production decreased in Rabi season.

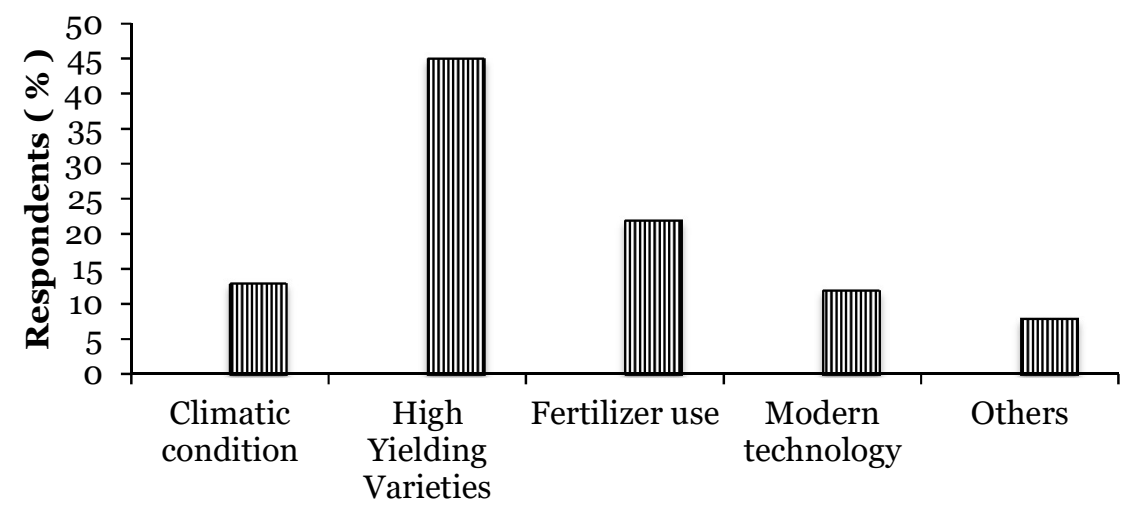

Causes

Fig. 17. Causes of increasing crop production.

\section{Fish production}

Annual fish production in Bhola Sadar: Overall, fish production in this upazila has slightly increased between 2007 and 2017. The highest production was identified in 2016-2017. Due to cyclone Sidr of 2007, cyclone Aila of 2009, and cyclone Mahasen of 2013, fish production in pond was reduced remarkably (Fig. 18). 


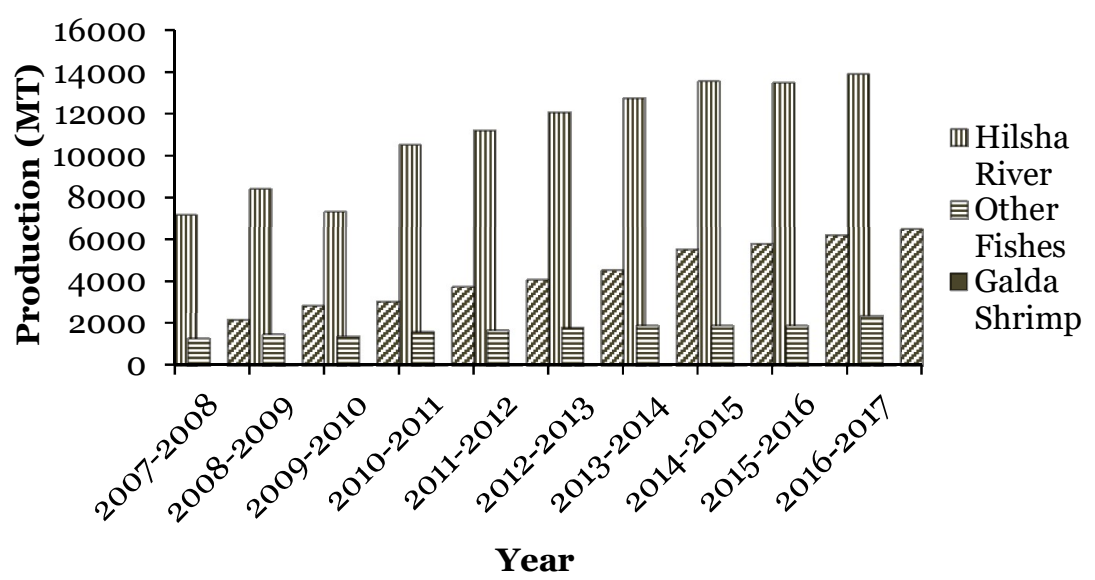

Fig. 18. Annual fish production in Bhola Sadar Upazila.

Annual fish production in Manpura: Overall, the affected the pond fish culture. The study found highest production of fishes was in 2016-2017. that due to cyclone Aila and cyclone Mahasen in During cyclones, water normally rise up to several 2009 and 2013; pond or hatchery fish meters and flash out fisheries and destroy other productions were decreased significantly in flora and fauna (Karim and Mimura, 2008). Due Monpura upazila (Fig. 19). But Overall Hilsha fish to cyclone Sidr in 2007, tidal surges adversely production was increased.

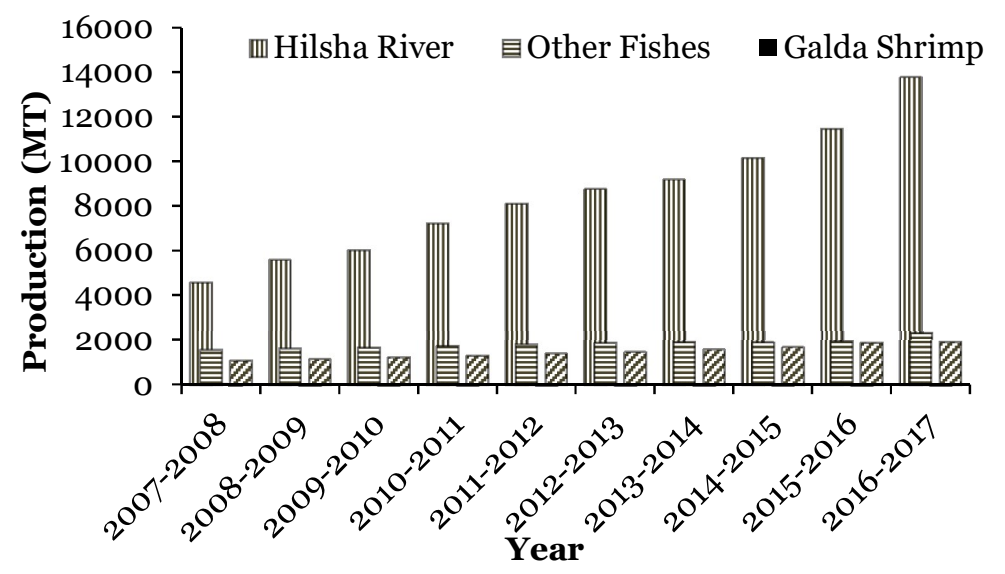

Fig. 19. Annual fish production in Manpura Upazila.

Impact on fish production: The $82 \%$ of the initiatives, while $13 \%$ said production was respondents who were fisherman said production decreasing and $5 \%$ had no idea about changes in was increasing due to different government the fish production amounts (Fig. 20).

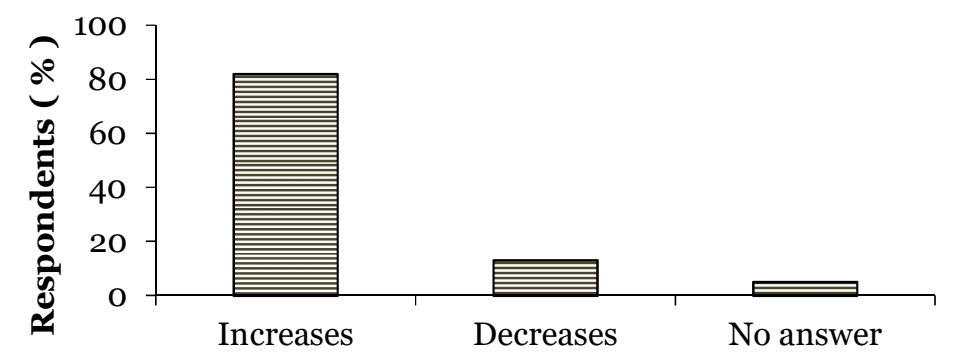

Production

Fig. 20. Perception on fish production. 
Impact on fish species: The $53 \%$ of the respondents said they get mostly Hilsha fish in Bhola district, $35 \%$ said pond fishes are also abundant in Bhola and Manpura upazila, 7\% respondents mentioned about shrimp, and 5\%

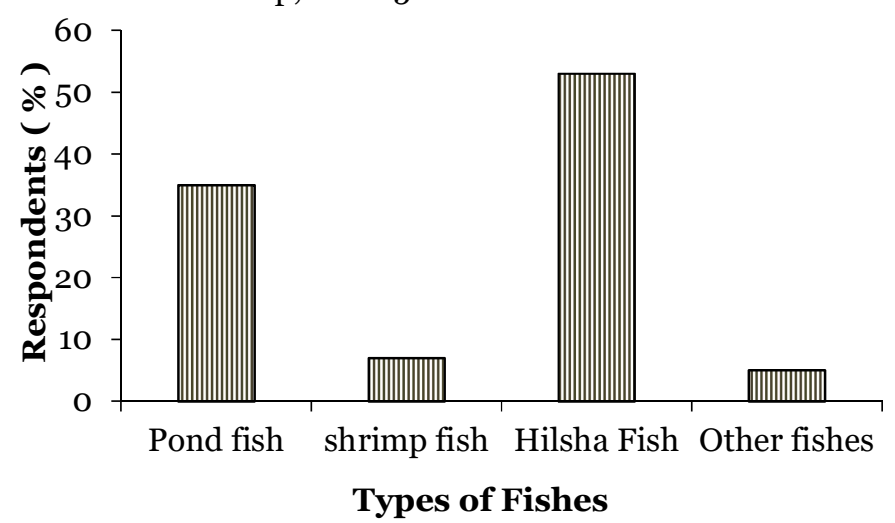

Fig. 21. Types of fishes found in the study area.

Causes of increasing fish production: The $40 \%$ of the respondents said timely raids by the authority increased fish production. Whereas 11, 23 and $25 \%$ of the respondents think that government initiative (like expedition against jatka fish

catching, banned current net, provide incentive to the fisherman for not catching fish during spawning time of Hilsha), climatic condition and all of these factors, respectively were behind the fish production increased (Fig. 22).

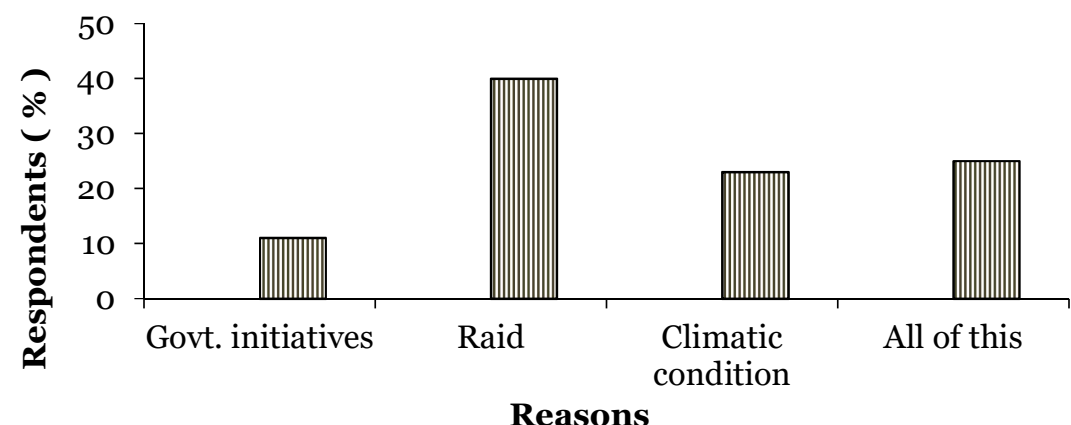

Fig. 22. Causes of increasing production

According to FGD and KII, fish production is increasing because of strict rules, raid and other activities conducted by fisheries and government authority. The government has set 4 fish sanctuary and prohibits catching of fish from 1st November to 31st May and catching of mother Hilsha from 15th October to 24th October. These initiatives ultimately leading to increase in fish production in Bhola district.

\section{Conclusions}

Climatic variables are changing over time that leads to natural disasters. The impacts of frequently occurring natural disasters on crop production are evident in the coastal region of Bangladesh as well as in the study area. The Aus, Aman, Mung bean production is increasing, while Boro production is decreasing. Initiatives provided by agriculture extension office such as provision of high yielding varieties; adoption of salt resistant variety, proper training, manure application, incentives, and mixed cropping pattern are the main reasons behind increased crop production. The study finds that fish production is also increasing in both upazila of Bhola district. The reasons may include government initiatives like raid in restricted time period in the year, laws on prohibiting harmful fish net, provision of incentives during nonfishing period, proper training among fisherman, etc. However, recurrent and severe natural disasters as a manifestation of climate change impact may hinder and reduce productions despite of currently successful government initiatives.

\section{Recommendation}

Farmers can increase crop production by using proper fertilizer, insecticide and by using good quality seeds. So, Agriculture Extension office can take actions extensively to disseminate the message to the farmers about the benefits of high 
yielding varieties. Proper operation of embankments should be ensured for protecting agriculture, fish culture in ponds from saline water, storm surges and floods. Changes should be brought into the whole farmers community about cropping pattern, more be focused on mix cropping pattern and priority on HYV cultivation in the cyclone affected areas. Governmental organization like fisheries department, coast guard and other organization can take expedition activities during non-fishing periods and they should also rising up expedition activities by banning harmful net to protect jatka fish. Develop climate-forecasting system to reducing hazards.

\section{Acknowledgement}

Sincere appreciation to the Social Science Research Council, Planning Division, Ministry of Planning (MoP) for financial support (Grand Serial \# Fellowship Research 17-182, 2018-2020) to carry out the research works successfully.

\section{References}

Badjeck, M.C., Allison, E.H., Halls, A.S. and Dulvy, N.K. 2010. Impacts of climate variability and change on fishery-based livelihoods. Marine Policy. 34(3): 375-383. https://doi.org/10.1016/j.marpol.2009.08.007

Banglapedia. 2017. National Encyclopedia of Bangladesh. Available online at: http://www.banglapedia.org/httpdocs/HT/ $\mathrm{W}-0053$.

Basak, J.K. 2010. Climate change impacts on rice production in Bangladesh: Results from a Model, Unnayan Onneshan- the innovators, Dhanmondi, Dhaka-1209, Bangladesh. pp. 50-56.

Basak, J.K., Titumir, R.A. and Dey, N.C. 2013. Climate change in Bangladesh: a historical analysis of temperature and rainfall data. $J$. Environ. 2(2): 41-46.

CCC (Climate Change Cell). 2009. Characterizing long-term changes of Bangladesh climate in context of agriculture and irrigation, Department of Environment, Dhaka. pp. 5657.

Chowdhury, A. 2002. Disasters: issues and responses. Bangladesh Environment: Facing the $21^{\text {st }}$ Century (2 ${ }^{\text {nd }}$ ed.), Ed. Gain P., Dhaka: Society for Environment and Human Development (SEHD). pp. 217-235.

DMB (Disaster Management Bureau). 2010. National Plan for Disaster Management. Disaster Management and Relief Division, Ministry of Food and Disaster Management, Government of the People's Republic of Bangladesh. pp. 90-96.

Gornall, J., Betts, R., Burke, E., Clark, R., Camp, J., Willett, K. and Wiltshire, A. 2010. Implications of climate change for agricultural productivity in the early twenty- first century. Philos. Trans. Royal Soc. B: Biol. Sci. 365(1554): 2973-2989.

https://doi.org/10.1098/rstb.2010.0158

Hasan, M.K., Hasan, M.K. and Hasan, M.K. 2014. Impact of climate change and variability on fisher livelihoods of coastal communities: A study on Dhalchar at Bhola district of Bangladesh. Open J. Ocean Coastal Sci. http://www.scipublish.com/journals/OCS/papers /download/3003-870.pdf.

IPCC (Intergovernmental Panel on Climate Change). 2007. Climate change 2007: Fourth assessment report. pp. 60-65. https://doi.org/10.1017/CBO9780511546013

IPCC (Intergovernmental Panel on Climate Change). 2012. Glossary of terms. In: Managing the Risks of Extreme Events and Disasters to Advance Climate Change Adaptation [Field, C.B., V. Barros, T.F. Stocker, D. Qin, D.J. Dokken, K.L. Ebi, M.D. Mastrandrea, K.J. Mach, G.K. Plattner, S.K. Allen, M. Tignor, and P.M. Midgley (Eds.)]. A Special Report of Working Groups I and II of the Intergovernmental Panel on Climate Change (IPCC). Cambridge University Press, Cambridge, UK, and New York, NY, USA. pp. 555-564.

IRRI (International Rice Research Institute). 1993. IRRI Rice Almanac (1993-1995), Los Bafios, Philippines, 142p.

Islam, M.S., Parvin, S., Emu, I.J. and Kabir, M.H. 2019. Impacts of river bank erosion on char livelihood and its adaptation techniques. Bangladesh J. Envron. Sci. 36: 23-32.

Karim, M.F. and Mimura, N. 2008. Impacts of climate change and sea-level rise on cyclonic storm surge floods in Bangladesh. Global Environ. Change. 18(3):490-500.

https://doi.org/10.1016/j.gloenvcha.2008.05.002

Karim, R. 2010. Sustainability views of adaptation measures to the potential impacts due to climate change in the coastal zone of Bangladesh. Royal Inst. Tech. 1(1): 18-24.

Kotir, J.H. 2011. Climate change and variability in Sub-Saharan Africa: a review of current and future trends and impacts on agriculture and food security. Env. Dev. Sust. 13(3): 587605.https://doi.org/10.1007/s10668-010-9278-o

MoEF (Ministry of Environment and Forest). 2009. Bangladesh climate change strategy action plan: 2009. Government of the People's Republic of Bangladesh. pp. 80-85.

NDP (National Development Program). 2013. Flood Situation Report 2013. Government of the People's Republic of Bangladesh. pp. 1518.

Neogi, M.G. and Erskine, W. 2017. Climate smart agriculture in coastal Bangladesh. The Daily Sun (Bangladesh), 24 ${ }^{\text {th }}$ October 2017. 
Rahman, M.H., Rahman, M.S. and Rahman, M.M. 2017. Disasters in Bangladesh: Mitigation and Management. Barisal Univ. J. 4(1): 139-163.

Rajib, M.A., Mortuza, M.R., Selmi, S., Ankur, A.K. and Rahman, M.M. 2011. Increase of heat index over Bangladesh: impact of climate change. World Acad. Sci. Eng. Tech. 58: 402-405. https://doi.org/10.5281/zenodo.1082207

Rashid, M.H. and Islam, M.S. 2007. Adaptation to climate change for sustainable development of Bangladesh agriculture. Bangladesh Agriculture Research Institute, Joydebpur, Gazipur. pp. 40-45.

Rimi, R.H., Rahman, S.H., Karmakar, S. and Hussain, S.G. 2009. Trend analysis of climate change and investigation on its probable impacts on rice production at
Satkhira, Bangladesh. Pak. J.

Meteorol. 6(11): 37-50.

https://doi.org/10.1088/1755-1307/6/47/472014

Shahid, S. 2010. Recent trends in the climate of Bangladesh. Climate Res. 42(3): 185-193. https://doi.org/10.3354/croo889

Shamsuddoha, M. and Chowdhury, R.K. 2007. Climate change impact and disaster vulnerabilities in the coastal areas of Bangladesh. COAST Trust, Dhaka. pp. 4048.

Tol, R.S. 2009. The economic effects of climate change.J. Econ. Persp. 23(2): 29-51. https://doi.org/10.1257/jep.23.2.29

UNDP (United Nations Development Programme). 2006. Bangladesh: Disaster Risk Reduction as Development. Available at http://www.albd.org/index.php/en/resources/sp ecial-reports/1387-disaster-managementinstitution-policies-and-legal-framework. 